\title{
Disease, Drugs and Dysbiosis: Understanding Microbial Signatures in Metabolic Disease and Medical Interventions
}

\author{
Ceri Proffitt $^{1, *}$, Gholamreza Bidkhori ${ }^{1}$, David Moyes ${ }^{1}$ and Saeed Shoaie ${ }^{1,2, *}$ \\ 1 Centre for Host-Microbiome Interactions, Faculty of Dentistry, Oral \& Craniofacial Sciences, \\ King's College London, London SE1 9RT, UK; gholamreza.bidkhori@kcl.ac.uk (G.B.); \\ david.moyes@kcl.ac.uk (D.M.) \\ 2 Science for Life Laboratory, Department of Protein Science, KTH Royal Institute of Technology, \\ 11417 Stockholm, Sweden \\ * Correspondence: ceriproffitt@kcl.ac.uk (C.P.); saeed.shoaie@kcl.ac.uk (S.S.)
}

Received: 16 July 2020; Accepted: 8 September 2020; Published: 9 September 2020

\begin{abstract}
Since the discovery of the potential role for the gut microbiota in health and disease, many studies have gone on to report its impact in various pathologies. These studies have fuelled interest in the microbiome as a potential new target for treating disease Here, we reviewed the key metabolic diseases, obesity, type 2 diabetes and atherosclerosis and the role of the microbiome in their pathogenesis. In particular, we will discuss disease associated microbial dysbiosis; the shift in the microbiome caused by medical interventions and the altered metabolite levels between diseases and interventions. The microbial dysbiosis seen was compared between diseases including Crohn's disease and ulcerative colitis, non-alcoholic fatty liver disease, liver cirrhosis and neurodegenerative diseases, Alzheimer's and Parkinson's. This review highlights the commonalities and differences in dysbiosis of the gut between diseases, along with metabolite levels in metabolic disease vs. the levels reported after an intervention. We identify the need for further analysis using systems biology approaches and discuss the potential need for treatments to consider their impact on the microbiome.
\end{abstract}

Keywords: metabolic diseases; metagenomics; systems biology; dysbiosis; gut microbiota

\section{Introduction}

Microbiota is the collective term for the ecosystem of microbial organisms living in a particular habitat. These ecosystems occupy a wide variety of habitats, including environmental regions such as coastal marine environments [1], animal environments (e.g., murine gut [2]) and human niches such as the skin [3], blood [4], mouth [5], nasal cavity [6] and gut [7]. The largest and most studied microbiome in humans is in the gut [8] with the oral cavity a close second. The gut microbiome community is made up of more microbial cells than there are human cells in the body, giving rise to hypotheses that it should be treated as a human organ [9]. The gut microbiome is impacted by several different sociodemographic factors such as age [10], geography [11], diet [12] and exercise [13]. It constantly evolves, growing and adapting depending on environmental factors and bacterial relationships. Bacterial species within these communities interact on a variety of levels via mutualistic, commensal, competitive or other relationships. These communities are far from inert, having an impact on their hosts in a variety of ways. As we have evolved, so too have these communities, developing a population that exists in parallel to their host. We now believe that the microbiome and factors affecting it are highly significant in human health [12]. These diverse ecosystems have various impacts on host physiology, such as modulation of the immune system by short chain fatty acid production (known to regulate $\mathrm{T}$ cell 
numbers) [14]. Further, these communities provide protection from pathogenic invasion through niche competition [15] and can aid in food digestion, in particular the breakdown of fibre [16].

However, when the environment of a habitat is disturbed this can alter the composition of microbial species in the eco-system [17]. These alterations can result in an imbalance between the host and microbial community or a reduction in microbial diversity in the gut known as dysbiosis. Many previous studies show the impact gut dysbiosis has in human diseases, such as type 2 diabetes [18], atherosclerotic cardiovascular disease (ACVD) [19], obesity [20] and liver cirrhosis [21].

As well as environmental changes, dysbiosis in the gut microbial communities can be caused by medical intervention such as drug use and bariatric surgery [22]. Antibiotics have been shown to profoundly alter the microbiota, supressing growth/presence of some species, thereby causing a loss of diversity [23]. Proton pump inhibitors (PPIs) used for inhibiting stomach acid production have been associated with high levels of oral bacteria in the gut, potentially by degrading the stomach acid barrier to microbial colonisation [24]. Metformin has been associated with reducing local inflammation and lipid absorption which can then alter the microbiome to significantly increase Escherichia species [25]. Gastric bypass surgeries (GBs) are a highly effective procedure for morbidly obese patients, who commonly suffer from obesity-related co-morbidities. With their impact on gastric function and nutrient passage, these procedures can also cause disruption to gut microbial composition. GBs have a direct effect on the microbiome, and recent studies have indicated that changes induced in the microbiome may facilitate some of the positive effects of surgery [26]. It is important to understand mechanisms behind the behaviour in the microbiome of metabolic disease and drug interventions. This will allow for a more targeted approach to treating disease via the microbiome. Here we review the dysbiosis associated with metabolic diseases, the effect medication has on the microbiota and assess the changes caused by a gastric band procedure.

\section{Alterations in the Microbiome Associated with Disease}

The three most common metabolic diseases are obesity, type 2 diabetes (T2D) and ACVD. Obesity, defined by having a body mass index (BMI) of more than 30, is a growing concern globally for health and wellness [27], and diagnosed cases of T2D are of equal concern. T2D, caused by insulin resistance, means the blood sugar levels become too high. Both these conditions could be impacted by diet, genetics and environment [28]. ACVD is a coronary condition that is caused by formation of a plaque (comprised of fat, cholesterol, calcium and other substances such as macrophages and fibroblasts) within the arteries that supply the heart. In a 2016 World Health Organisation (WHO) report an estimated 422 million adults worldwide suffered from T2D, while more than 1 in 10 adults were obese [29]. Likewise, cardiovascular disease is the number one cause of mortality worldwide [30]. These diseases are associated with sex, age, geography and other factors [31]; in particular diet and genetics are both important influences [28]. Importantly, these diseases are common comorbidities for each other [32]. These diseases are end points to many other conditions which belong to the category of metabolic syndrome. They are the most serious stages of disease which can lead to hospitalisation and surgery. However, conditions such as hypertension, which are symptomless, can go unnoticed for years [33] and are often intertwined with diseases such as T2D and obesity; with up to $75 \%$ of diabetic patients suffering from hypertension [34,35]. Notably, even in these common symptomless comorbidities, there are already effects on the gut microbiome composition [36].

Obesity, T2D and ACVD have been linked to dysbiosis in the gut microbiome. For each disease, the metagenomic signatures varied. However, there are key genera which are found to be significantly increased or decreased when compared to the matched controls in more than one study (Supplementary Table S1). Across studies we have focused on reporting the genus and phylum level bacterial signatures, and summarise the bacterial signature overlap between the different diseases.

Studies comparing patients of these diseases with healthy matched controls showed dysbiotic bacterial signatures within the gut microbiome [18,20,37-39]. For each of these diseases, there were alterations at genus and phylum level in the microbiome. All three metabolic diseases showed an 
increase in Actinobacteria and a decrease in Bacteroidetes. Results also revealed six genera increased in obesity, T2D and ACVD (Clostridium, Collinsella, Fusobacterium, Lactobacillus, Megasphaera and Veillonella); while Roseburia was the only genus shown to be consistently decreased across all three metabolic diseases (Figure 1A) [19,20,37-39].

A

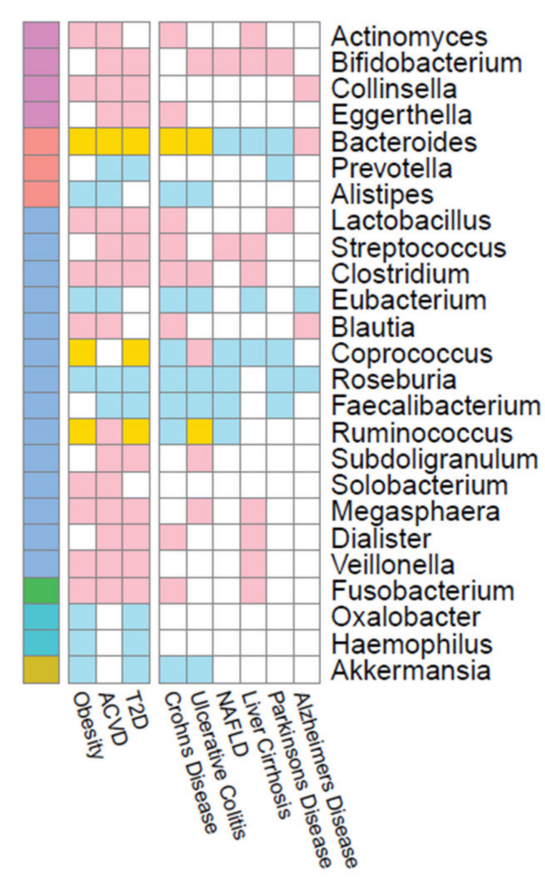

B

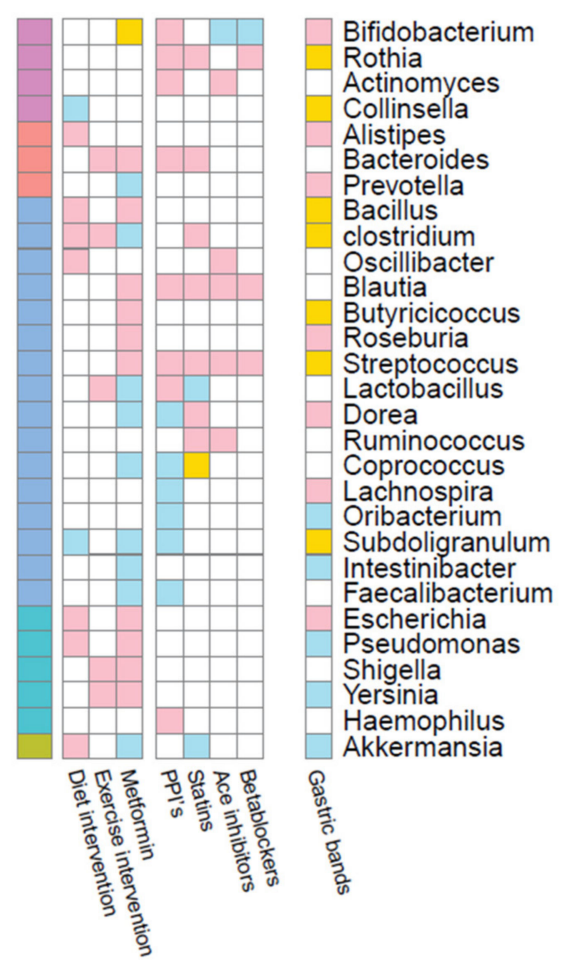

Actinobacteria Bacteroidetes Firmicutes Fusobacteria Proteobacteria Verrucomicrobia

Contradictory Decreased Increased

Figure 1. Genus signatures observed throughout the diseases and medical interventions. (A) Specific genera signatures observed to be statistically significant in metabolic diseases compared to healthy match controls; including obesity, type 2 diabetes (T2D) and atherosclerosis (ACVD) and also observed in Crohn's disease, ulcerative colitis, non-alcoholic fatty liver disease (NAFLD), liver cirrhosis, Parkinson's disease and Alzheimer's disease. (B) Specific genera signatures observed in medical interventions and drug treatments including diet and exercise interventions, metformin, proton pump inhibitors (PPIs), statins, angiotensin-converting-enzyme (ACE) inhibitors and betablockers. (C) Specific genera signatures observed in medical interventions also observed in gastric band surgery, including laparoscopic adjustable Gastric band, vertical sleeve gastrectomy and gastric roux-en-y bypass. For all panels blue indicates the genus is reported as decreased in disease than in healthy controls, red indicates the genus is reported as increased in disease than in healthy controls. Yellow shows the genus has been reported increased and decreased in different studies.

Metabolic diseases are known to be co-morbidities of other ailments, hence we compared studies of metagenomic analyses from inflammatory bowel disease (IBD), liver diseases and neurodegenerative diseases; as all these diseases could be associated to the gut microbiome. IBD is the term used to cover ulcerative colitis (UC) and Crohn's disease (CD). Both affect the gut though inappropriate, unrestrained inflammation and cause ulcers in the intestine [40]. When comparing IBD patients with healthy controls, bacterial signatures showed an overlap with metabolic disease signatures. Notably, Actinobacteria (including Actinomyces, Bifidobacterium and Eggerthella) are reported to be enriched in IBD- and MD-patients whilst five genera were decreased in abundance in both IBD diseases and metabolic diseases (Alistipes, Eubacterium, Roseburia, Feacalibacterium and Akkermanisa) [37,41-44]. These are known short chain fatty acid producers which are beneficial to health, hence a reduction in these genera could lead to poor health. 
Obesity and T2D are both common comorbidities of liver problems with $80-90 \%$ of obese patients and $70 \%$ of T2D patients suffering with non-alcoholic fatty liver disease (NAFLD) [45]. NAFLD NAFLD is defined by the accumulation of fat in the liver in those who consume little to no alcohol. NAFLD can in some cases lead to inflammation and scaring of the liver tissue. However, liver cirrhosis is a liver disease which involves scarring of the organ tissue leading to malfunction, often caused by poor diet with excessive alcohol consumption. Similarly to IBD, when comparing liver failure bacterial taxonomic signatures with metabolic diseases there were some concordant results. As for other diseases, Actinobacteria are increased in abundance in cirrhosis [41]. Liver cirrhosis also showed consistent enrichment of genera in the Firmicutes phylum, including Streprococcus, Clostridium, Megasphaera, Dialister and Fusobacterium which were also enriched in MDs [37,46-48]. It is not just gut-associated ailments that are impacted by the microbiome. Increasingly, neurodegenerative diseases have been associated with the gut microbiome via the gut-brain-axis. They have also been increasingly associated with metabolic disease, in particular obesity [49]. Alzheimer's, the most common neurodegenerative disease, results in an unrepairable loss of neurons [50] whilst Parkinson's disease, another common neurodegenerative disease, is commonly characterised by tremors, rigidity and instability [50]. Both the conditions show decreased numbers of genera from the phylum Firmicutes, in contrast to liver disease. However, the few genera present show enrichment, discordant with other diseases [51-54].

In all three metabolic diseases and the comorbidities, clinical cohort studies have shown the consistent depletion of the genera Eubacterium, Roseburia and Feacalibacterium in diseased patients. Notably, these are all butyrate producing bacteria. This important short chain fatty acid plays a key role in maintaining health and inhibiting inflammation [55]. Other genera, including Bacteroides, Coprococcus and Ruminococcus showed inconsistent trends across different diseases. Bacteroides enterotype is associated with long-term diet choices, usually high protein [56]. It is well known the relationship between diet and the microbiome can contribute to the development of disease. However, when reviewing this literature, it is key that we interpret their findings with caution. Each of these studies used different designs and sequencing techniques as well as other variations in the data, such as geographical region or age of the participants. These are all factors which, as stated above, are known to impact on both microbiome and on the disease phenotype itself.

\section{Alterations in the Microbiome Associated with Medical Intervention or Treatment}

Much like the gut microbiome is associated with disease progression and phenotype it is increasingly being implicated in drug pharmacology and drug mechanism. Microbial consortia and function can be altered due to the impact of drugs or other interventions, such as low-calorie diets, exercise regimes or surgery $[57,58]$. Natural products such as probiotics, prebiotics and synbiotics (such as sauerkraut, kimchi and live yoghurt) can also affect the microbiome [59]. These products are often considered beneficial for gut health. Here, we specifically review commonly used medical interventions with acknowledged clinical effectiveness and hence is the best known treatment derived from research and clinical experience to achieve optimum outcome. As such, although likely effective, natural products fall out of the scope of this review.

The extent of drug-induced alterations made to the gut microbiome are unique to every person, down to the compositional changes at strain-level [58]. Additionally, they noted the potential role microbes play in metabolising drugs [58]. Therefore, we must start considering the gut microbiome as a key factor in drug therapy as well as in disease [60]. Some drugs specifically target bacteria (such as antibiotics), whilst the mechanism of others such as increased production of short chain fatty acids (SCFAs) is linked with the microbiome (such as metformin) and others alter the microbial composition (such as PPIs). However, the effect these drugs have on the microbiome is not considered when prescribing them. Recently, studies have started looking at the impact drugs or interventions have on the gut microbiome (Supplementary Table S2). 


\subsection{Alterations in the Gut Microbiome Due to Diet and Exercise Interventions}

Obesity and T2D are both predominantly caused by excessive food intake and lack of exercise [61]. Hence, the first line of treatment for obesity is usually a diet resulting in a calorific intake deficit and increased exercise. Diet-induced weight-loss interventions appear to improve microbiome composition and clinical phenotypes [62]. Several studies have exposed differences between the composition of lean versus obese subjects, and many groups have reported changes to lifestyle impacts the gut microbiome composition [63]. Metagenomic studies have now started to examine obese or overweight patients to examine the functional impact the changes to the microbiome have on the disease [62,64]. In T2D, low grade inflammation caused by poor diet is considered responsible for insulin resistance [65]. There is robust evidence for exercise treating or preventing T2D, and interestingly there is also evidence of regular exercise influencing the gut microbiome composition $[64,66]$. However, it is currently unclear whether this influence is on the microbes directly or via the impact exercise has on the host. To investigate these lifestyle alterations, studies have put obese patients on a low-calorie diet and exercise therapy over 24 months [64] or T2D patients through a 6-month exercise program [13]. Metagenomic analyses of stool from these cohorts at baseline and study-end showed an increased abundance in Proteobacteria with both interventions. However, increased abundance of Proteobacteria has also been associated with metabolic diseases and been identified as a potential microbial signature of disease. Hence, it is possible that whilst these interventions treated the symptoms of the diseases, their impact on the microbiome was not as positive.

\subsection{Alterations in the Gut Microbiome Due to Metformin}

After lifestyle intervention, metformin is the first drug used to treat T2D where it acts as an antihyperglycemic [67], supressing hepatic gluconeogenesis [68] and increases skeletal muscle tissue glucose uptake [69]. However, to date, the complete mechanism of action of metformin is still unknown. There is mounting evidence to suggest that the drug interacts with the gastrointestinal tract and studies have shown that metformin treatment also has a significant impact on the microbiome [70-72]. E. H. Ejtahed et al. [71] noted the weight loss seen in diabetics treated with metformin, and hence studied the impact of metformin treatment in non-diabetic obese patients on their gut microbiome composition. They showed treatment with metformin caused significant weight-loss in conjunction with distinct differences in taxonomy between baseline and post treatment. Concordant results from both studies showed increases in the phylum Proteobacteria including Escherichia, Pseudomonas, Shigella and Yersinia.

\subsection{Alterations in the Gut Microbiome Due to Cardiovascular Drugs}

T2D and obesity are both often comorbidities of cardiovascular disease. ACVD is a cardiovascular disease which affects arterial walls [73]. Atherosclerotic plaques restrict blood flow through the coronary arteries. This plaque build-up is often caused by environmental factors such as high-fat diet, smoking and lack of exercise. Hence, it is not surprising the recommended treatment for ACVD when first diagnosed is increased exercise and following a healthy diet. Medication is often used to manage the symptoms of ACVD and prevent the disease from worsening. Statins are widely used for the treatment of high cholesterol [74]. These drugs promote the reduction in levels of LDL cholesterol [75] and can have anti-inflammatory effects [76]. Vieira-Silva et al. noted that a microbial composition associated with obesity was negatively associated with statin use. They also commented on the potential of statin treatment in the management of microbial dysbiosis in the gut by improving the inflammation status of the host [77]. Statins are not the only drugs used in the treatment of ACVD symptoms. Angiotensin-converting-enzyme (ACE) inhibitors treat high blood pressure and heart failure whilst $\beta$-blockers manage abnormal heart rhythms that occur in ACVD. Whilst PPIs are not used directly for cardiovascular complaints, they are often taken in conjunction with medication such as antiplatelets or aspirin as these drugs can cause indigestion and heartburn. PPIs are 
known to impact the microbiome [78,79] by the inhibiting secretion of gastric acid which increases the number of surviving microbes that pass through the stomach to reach the intestine [80]. In doing so, PPIs significantly alter the gut microbiome, with an increase in Actinobacteria at the phylum level, including Bifidobacterium, one of the most represented genera of Actinobacteria in the human gut. Despite all these drugs having different mechanisms, they have notably similar effects on microbiome composition, all causing an increase in Blautia and Streptococcus for example (Figure 1B) [78]. This could be due to the drugs having comparable functional effects on the microbial pathways, hence causing analogous outcomes in taxonomic profiles.

\subsection{Alterations in the Microbiome after Gastric Band Surgery}

Although dietary change and increased exercise is the standard recommended treatment for obesity, the results are varied predominantly due to variations in patient compliance. In contrast, bariatric surgical intervention is currently the most effective treatment for obesity; for example, patients who also suffer from T2D go into remission post intervention [26,81,82]. This surgical intervention could result in rapid weight loss, improved glucose metabolism and improved insulin sensitivity [83]. The three most common surgeries are laparoscopic adjustable Gastric band [84]; vertical sleeve gastrectomy (VBG) [26] and a gastric roux-en-y bypass (RYGB) [82,85]. Studies have indicated that gastric band surgery has beneficial effects on the composition of the gut microbiome [86]. These surgery-induced changes are usually associated with metabolic improvements. However, it is important to note these changes could be due to the decreased capacity of food intake or different dietary regime. Comparing the composition of the microbiome pre- and post-surgery with other interventions, there is a large overlap in those genera seen to be significantly affected by the surgery (Figure 1C) [26,82-87]. Many studies investigated the impact of the roux-en-y surgery on the gut microbiome [26,82-87]. RYGBs clinical cohort studies showed many genera in Actinobacteria and Proteobacteria were increased after surgery (Supplementary Table S3). There are clearer differences in microbial composition in those who underwent RYGB surgery compared to those who had VBG surgery, when compared to the patients' pre-surgery microbiome [26]. Tremaroli et al. determined Escherichia, Klebsiella and Pseudomonas (all from Proteobacteria) were increased after RYGB, similar to the exercise and diet interventions mentioned earlier [26]. However, despite the differences between procedures they did not observe a significant difference in the microbial profiles between the two patient cohorts.

\section{Metabolomic Signatures in Metabolic Diseases}

The symbiotic metabolic relationship between host and microbiome is reflected not just in the taxonomical signature of the microbiome, but also in the integrated metabolism between host and microbiome. This integrated metabolism will affect metabolite levels present in both gut/stool and blood. As a result, these metabolites as well as providing potential biomarkers for disease may also affect the disease progression itself. Reported levels of metabolites in metabolic diseases and common interventions are shown in Figure 2. Notably, the parallels seen in the metabolite profiles between the diseases indicates that metabolic disease similarities do not end at the level of microbiota dysbiosis.

Metabolomic studies, comparing the small molecules and compounds found in the cells, tissues or biofluids of the host, have been performed across the different metabolic diseases. Despite different metabolomic approaches and obvious differences between the diseases, studies show a series of striking similarities in faecal and serum metabolite levels. In particular, there are consistent changes in serum levels of metabolites such as uric acid, cholesterol and inflammatory markers (including C-reactive protein metabolite (CRPM)), all common disease biomarkers. High levels of these metabolites (especially cholesterol and uric acid) in the bloodstream cause an inflammatory response, thus potentially driving disease progression. Thus, unsurprisingly, uric acid, cholesterol and inflammatory markers were all increased in metabolic diseases [88-94]. 


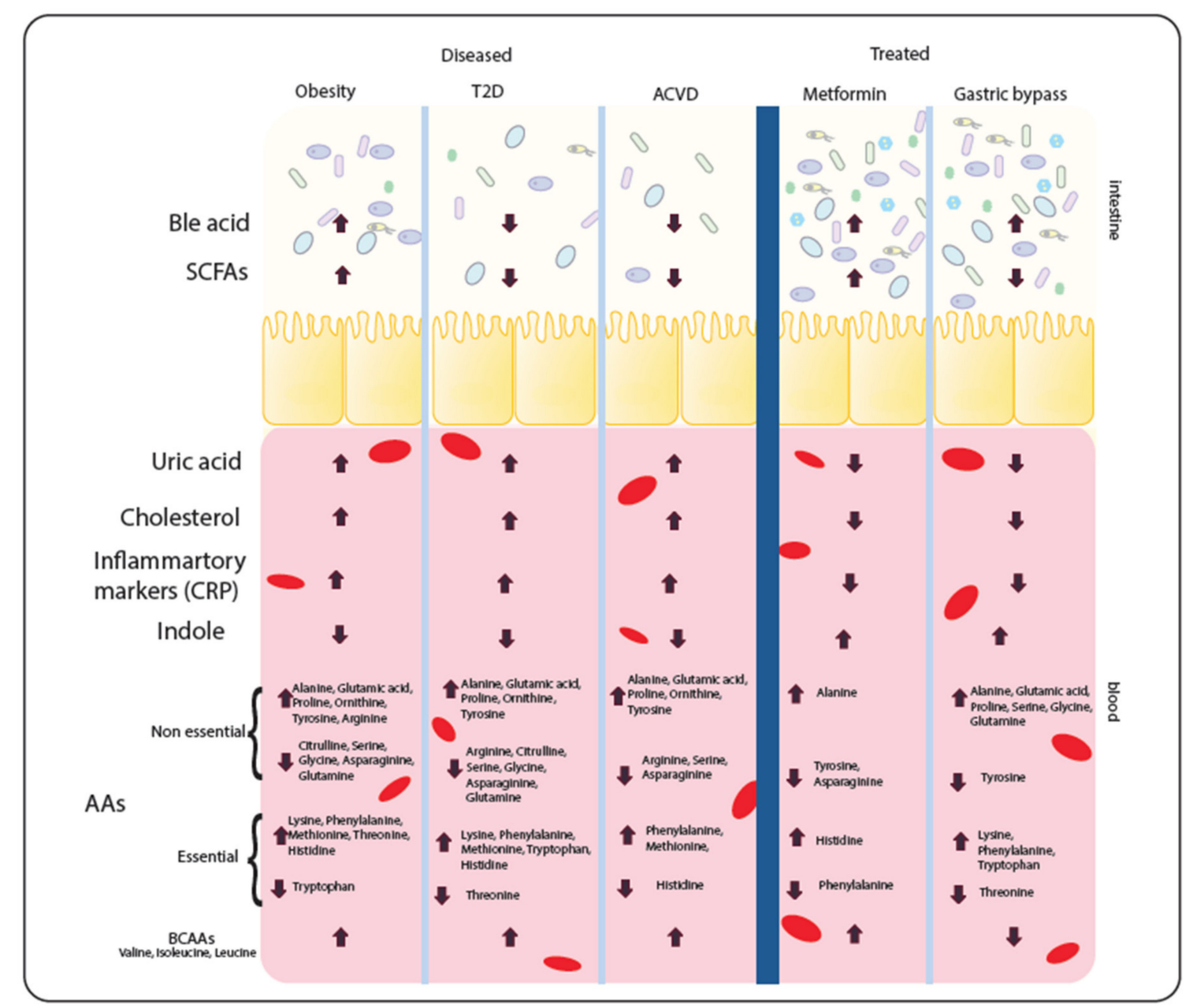

Figure 2. Metabolite levels seen in diseases and interventions. Dysbiosis in the intestine of metabolic disease patients causes alterations to the metabolite levels reported in faecal and serum samples. After treatment, the composition of the microbiome is altered again and hence the metabolite levels alter again. Here, specific metabolite levels which have been reported in metabolic disease (obesity, type 2 diabetes (T2D) and atherosclerosis (ACVD)) and the levels reported after metformin treatment or gastric band surgery. These are seen in the gut from stool samples or in the blood from serum/plasma samples. Metabolites noted with a down arrow are found to be decreased in the disease or treatment. Metabolites noted with an up arrow are found to be increased in the disease or treatment. Both an up and down arrow shows the metabolites vary in enrichment.

Serum metabolomics also showed depletion of indoles in all metabolic diseases [95,96]. Indoles are derived from tryptophan and are ligands for aryl hydrocarbon receptor (AHR), which in turn has an anti-inflammatory effect and stimulates $\gamma \delta$ T-cell development $[97,98]$. However, there was no correlation between serum amino acids and disease, except branch chain amino acids (BCAAs) which were increased in abundance in disease [99-102]. Potentially, elevated BCAA serum levels could therefore be a new biomarker for metabolic disease. The faecal metabolome also showed several common themes. SCFAs such as acetate, butyrate and propionate were seen to be decreased in both T2D and ACVD [89,103], whilst obesity has increased levels of SCFAs [104]. Bile acids, composed of cholesterol metabolites and serving as metabolic regulators of glucose, fat and energy metabolism [105] were reported increased in obesity [106], while T2D and ACVD showed decreased levels [18,107]. Bile acids can be beneficial and detrimental to human health, hence an imbalance in bile acids could exacerbate metabolic disease [108]. 
Post-medical intervention usually drives a shift in metabolite levels. Uric acid, cholesterol and inflammatory markers all show a decrease after metformin treatment or gastric band surgery [92,109-112] whilst indole levels increase, providing a contrasting metabolite profile to untreated cohorts $[95,113]$. Additionally, bile acids were increased post-intervention compared to untreated cohorts [114,115]. Faecal SCFAs show varying responses from interventions [26,95]. Metformin increased levels, as expected, whilst SCFA levels were decreased in T2D. On the other hand, GBs decrease the SCFA levels to counter the increased levels seen in obesity. Amino acids again showed no correlation with intervention. Notably, however, BCAAs were decreased after GB surgery [116,117]. The metabolite levels are dictated by the changing microbiome as much as by the host, as different species produce and consume different compounds. For example, Eubacterium (decreased in all diseases) has a negative correlation with cholesterol and inflammatory markers [118]. To understand these links more clearly, it is important to consider the metabolism of the species understand their metabolic interaction between each other and host to elucidate their role in the disease.

\section{A Systems Biology Approach to Further Understanding Disease}

Metagenomics and metabolomics studies have revealed the associations of microbial abundance and the metabolite profile to metabolic diseases. However, these associations are mediated by complex interactions between the microbes, host and environmental factors such as diet. Systems biology, with its holistic view of biological systems, integrates these multi-omics data sets. They allow for the development of mathematical models that can be applied in microbial ecosystems to mechanistically reveal the role of individual bacteria and their interactions in disease progression (Figure 3). This integrative approach provides significant insights into biological mechanisms [119]. The centre of this integration can be biological networks, including metabolic networks, signalling networks, protein-protein interactions, co-expression networks and gene regulatory networks [120-122]. Signalling networks provide frameworks for dynamic and static modelling of cell signalling, while protein-protein interaction networks give insights to the interaction of proteins which are integral to biological functions. Gene regulatory networks represent the link between transcription factors and genes. Among different network analyses, genome-scale metabolic models (GEM) describe the gene-protein-reaction relationships within an organism through collection of the various metabolic reactions, their stoichiometry information and compartmentalisation [120]. GEMs can be integrated with other biological networks to provide a more comprehensive view of the cellular behaviours.

Static and dynamic algorithms are commonly applied for modelling of biological networks such as kinetic, petri-net, stoichiometric, hybrid approaches and structural modelling [123]. Constraint-based modelling can also be applied to GEMs by introducing specific constrains (such as input substrates or gene expression data) to optimise an objective function (the reaction desired to be maximised or minimised). In most microbial cases biomass is the objective function used to predict cellular metabolism and biochemical production for both catabolic and anabolic processes [124]. Additionally, all the information needed for GEM reconstruction is a list of biochemical reactions and their stoichiometry matrix. With these unique capabilities, GEMs link genotype to phenotype, underlining the mechanism behind different conditions, such as cancer, metabolic disease or liver disease. In doing so, they identify potential new biomarkers and therapeutic interventions [121,125,126]. Recently, GEMs have been applied to microbial ecosystem. To do this GEMs for several species have been reconstructed [127] and applied to community-level analysis [120]. GEMs can be applied to understand the interaction between microbes by introducing the biomass as the individual objective functions governing the optimisation of the microbial ecosystems' growth as the community objective [128,129]. This allows us to investigate in silico how microbes respond to environmental alterations such as diet interventions, meaning we can quantitatively describe the change in the uptake or secretion of metabolites resulting from any intervention [130]. By combining microbial GEMs with a comprehensive host metabolic model, such as Recon 3D [131] the metabolic interactions between the microbial community and host can be studied [132]. This then opens the door to personalised community modelling that can be used 
for microbe-microbe interactions [133]. Thus, GEMs represent a powerful way forward to elucidate the causality of the microbial community changes to their associated diseases, revealing their metabolic role in both the gut and the wider host habitat.

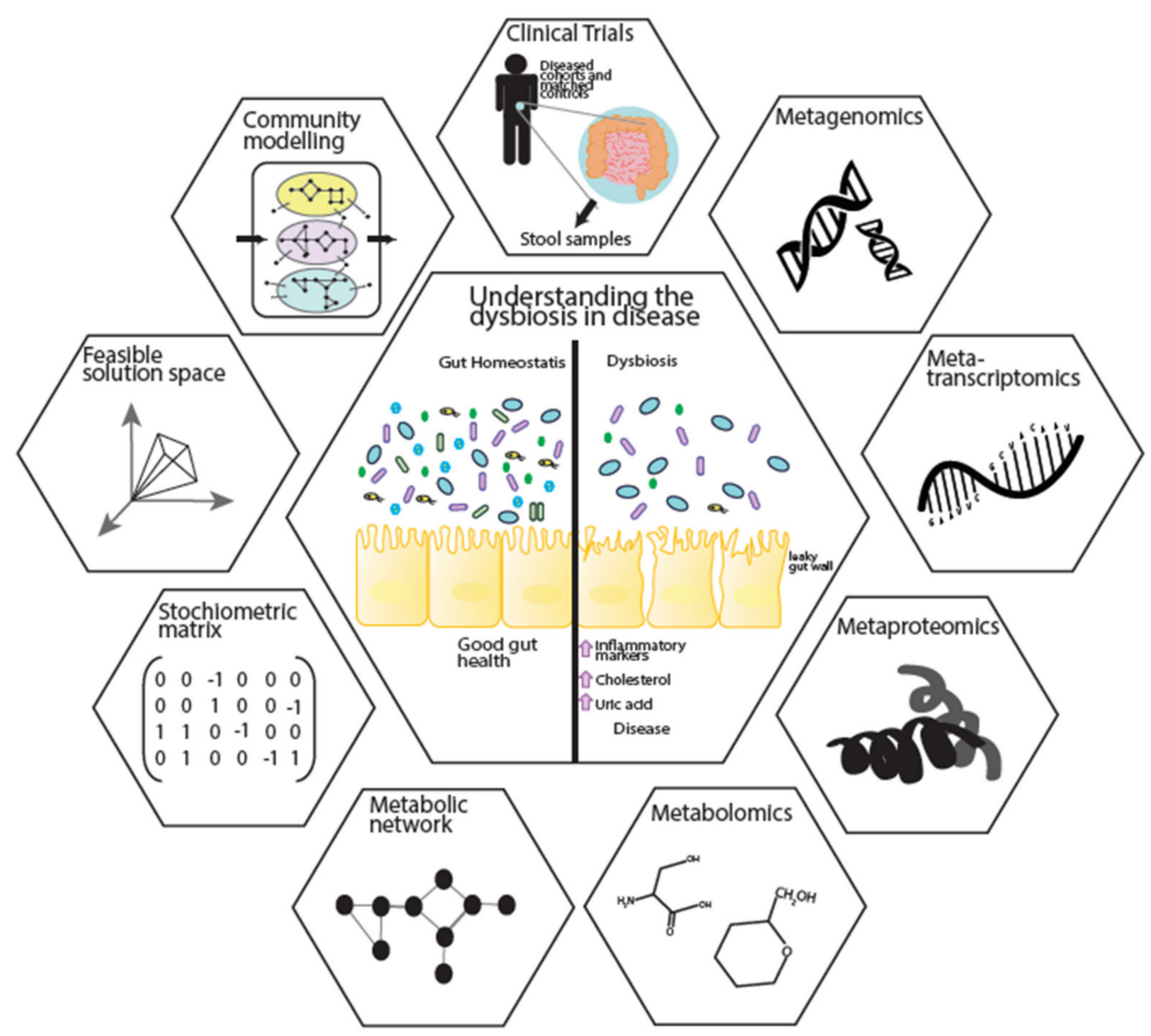

Figure 3. Application of GEMs in multi-omics data integration and ecosystem modelling. Clinical samples are taken from cohorts to generate multi-omics data, including metagenomics, metatranscriptomics, metaproteomics and metabolomics. Multi-omics data is used in the reconstruction of metabolic models. Constraint-based analysis can be applied on individual metabolic models to understand the metabolic capability of an organism. Following form individual modelling, community models can be created to show microbe-microbe and microbe-host interactions.

\section{Conclusions}

Despite having identified microbial association across the metabolic diseases, there is still a mechanistic understanding missing of how microbe-host interaction changes contribute to disease pathophysiology. Accumulating evidence indicates that these diseases are associated with each other and also have strong bidirectional links to the microbiome. Obesity, insulin resistance or cardiovascular disease are often co-morbidities and are increasingly seen with other diseases. Furthermore, the recommended treatments for these diseases do not simply impact the symptoms and host physiology - they also result in alterations to the gut microbiome. From a future perspective, there is a need for further studies and data generation of the alterations in the microbiome in all diseases. Additionally, clearly the effects drugs have on the microbiome should be considered in the risk assessment of new drugs, or should be considered as a potential target for medical interventions. The microbiome could be used in a novel method of attaining biomarkers for the progression of 
diseases. By targeting the microbiome directly, either through composition or metabolism, we can open up new avenues for managing these chronic, debilitating diseases most effectively.

Supplementary Materials: The following are available online at http://www.mdpi.com/2076-2607/8/9/1381/s1, Table S1: Bacterial taxa increased and decreased in diseases. $(\mathrm{N})$ is the number of studies data was taken from. Bold-genera that were reported in more than one study. Table S2: Bacterial taxa increased and decreased in medical interventions or after a course of medical drug treatment. $(\mathrm{N})$ is the number of studies data was taken from. Bold-genera that were reported in more than one study. Table S3: Bacterial taxa increased and decreased after gastric band surgery. $(\mathrm{N})$ is the number of studies data was taken from. Bold-genera that were reported in more than one study.

Author Contributions: Conceptualisation, C.P., D.M. and S.S.; investigation, C.P.; data curation, C.P.; writing-original draft preparation, C.P.; writing-review and editing, S.S., D.M. and G.B.; visualisation, C.P. All authors have read and agreed to the published version of the manuscript.

Funding: This study was supported by Engineering and Physical Sciences Research Council (EPSRC), (EP/S001301/1) award to SS, and a BBSRC award (BB/M009513/1) to DLM, as well as by funding from King's College London and Science for Life Laboratory.

Conflicts of Interest: The authors declare no conflict of interest.

\section{References}

1. Trevathan, S.M.; Sherman, C.D.; Huggett, M.J.; Campbell, A.H.; Laverock, B.; Hurtado-McCormick, V.; Seymour, J.R.; Firl, A.; Messer, L.F.; Ainsworth, T.D.; et al. A horizon scan of priorities for coastal marine microbiome research. Nat. Ecol. Evol. 2019, 3, 1509-1520. [CrossRef] [PubMed]

2. Cho, I.; Yamanishi, S.; Cox, L.M.; Methe, B.A.; Zavadil, J.; Li, K.; Gao, Z.; Mahana, D.; Raju, K.; Teitler, I.; et al. Antibiotics in early life alter the murine colonic microbiome and adiposity. Nature 2012, 488, 621. [CrossRef] [PubMed]

3. Byrd, A.L.; Belkaid, Y.; Segre, J.A. The human skin microbiome. Nat. Rev. Microbiol. 2018, 16, 143. [CrossRef] [PubMed]

4. Paissé, S.; Valle, C.; Servant, F.; Courtney, M.; Burcelin, R.; Amar, J.; Lelouvier, B. Comprehensive description of blood microbiome from healthy donors assessed by $16 \mathrm{~S}$ targeted metagenomic sequencing. Transfusion 2016, 56, 1138-1147. [CrossRef]

5. Wade, W.G. The oral microbiome in health and disease. Pharmacol. Res. 2013, 69, 137-143. [CrossRef] [PubMed]

6. Dominguez-Bello, M.G.; Costello, E.K.; Contreras, M.; Magris, M.; Hidalgo, G.; Fierer, N.; Knight, R. Delivery mode shapes the acquisition and structure of the initial microbiota across multiple body habitats in newborns. Proc. Natl. Acad. Sci. USA 2010, 107, 11971-11975. [CrossRef]

7. Arumugam, M.; Raes, J.; Pelletier, E.; Le Paslier, D.; Yamada, T.; Mende, D.R.; Fernandes, G.R.; Tap, J.; Bruls, T.; Batto, J.M.; et al. Enterotypes of the human gut microbiome. Nature 2011, 473, 174. [CrossRef]

8. Karlsson, F.H.; Tremaroli, V.; Nielsen, J.; Bäckhed, F. Assessing the Human Gut Microbiota in Metabolic Diseases. Diabetes 2013, 62, 3341-3349. [CrossRef]

9. Consortium, I.H.G.S. Finishing the euchromatic sequence of the human genome. Nature 2004, $431,931$.

10. Alfa, M.J.; Strang, D.; Tappia, P.S.; Graham, M.; Van Domselaar, G.; Forbes, J.D.; Laminman, V.; Olson, N.; DeGagne, P.; Bray, D.; et al. A randomized trial to determine the impact of a digestion resistant starch composition on the gut microbiome in older and mid-age adults. Clin. Nutr. 2018, 37, 797-807. [CrossRef]

11. Gaulke, C.A.; Sharpton, T.J. The influence of ethnicity and geography on human gut microbiome composition. Nat. Med. 2018, 24, 1495-1496. [CrossRef] [PubMed]

12. Singh, R.K.; Chang, H.-W.; Yan, D.; Lee, K.M.; Ucmak, D.; Wong, K.; Abrouk, M.; Farahnik, B.; Nakamura, M.; Zhu, T.H.; et al. Influence of diet on the gut microbiome and implications for human health. J. Transl. Med. 2017, 15, 73. [CrossRef]

13. Pasini, E.; Corsetti, G.; Assanelli, D.; Testa, C.; Romano, C.; Dioguardi, F.S.; Aquilani, R. Effects of chronic exercise on gut microbiota and intestinal barrier in human with type 2 diabetes. Minerva Med. 2019, 110, 3-11. [CrossRef] [PubMed]

14. Smith, P.M.; Howitt, M.R.; Panikov, N.; Michaud, M.; Gallini, C.A.; Bohlooly, M.; Glickman, J.N.; Garrett, W.S. The Microbial Metabolites, Short-Chain Fatty Acids, Regulate Colonic $\mathrm{T}_{\text {reg }}$ Cell Homeostasis. Science 2013, 341, 569-573. [CrossRef] 
15. Khosravi, A.; Mazmanian, S.K. Disruption of the gut microbiome as a risk factor for microbial infections. Curr. Opin. Microbiol. 2013, 16, 221-227. [CrossRef]

16. Shreiner, A.B.; Kao, J.Y.; Young, V.B. The gut microbiome in health and in disease. Curr. Opin. Gastroenterol. 2015, 31, 69-75. [CrossRef] [PubMed]

17. Lewis, J.D.; Chen, E.Z.; Baldassano, R.N.; Otley, A.R.; Griffiths, A.M.; Lee, D.; Bittinger, K.; Bailey, A.; Friedman, E.S.; Hoffmann, C.; et al. Inflammation, Antibiotics, and Diet as Environmental Stressors of the Gut Microbiome in Pediatric Crohn's Disease. Cell Host Microbe 2015, 18, 489-500. [CrossRef] [PubMed]

18. Zhao, L.; Lou, H.; Peng, Y.; Chen, S.; Zhang, Y.; Li, X. Comprehensive relationships between gut microbiome and faecal metabolome in individuals with type 2 diabetes and its complications. Endocrine 2019, 66, 526-537. [CrossRef]

19. Jie, Z.; Xia, H.; Zhong, S.-L.; Feng, Q.; Li, S.; Liang, S.; Zhong, H.; Liu, Z.; Gao, Y.; Zhao, H.; et al. The gut microbiome in atherosclerotic cardiovascular disease. Nat. Commun. 2017, 8, 845. [CrossRef]

20. Liu, R.; Hong, J.; Xu, X.; Feng, Q.; Zhang, D.; Gu, Y.; Shi, J.; Zhao, S.; Liu, W.; Wang, X.; et al. Gut microbiome and serum metabolome alterations in obesity and after weight-loss intervention. Nat. Med. 2017, 23, 859. [CrossRef]

21. Shao, L.; Ling, Z.; Chen, D.; Liu, Y.; Yang, F.; Li, L. Disorganized Gut Microbiome Contributed to Liver Cirrhosis Progression: A Meta-Omics-Based Study. Front. Microbiol. 2018, 9, 3166. [CrossRef] [PubMed]

22. Falony, G.; Joossens, M.; Vieira-Silva, S.; Wang, J.; Darzi, Y.; Faust, K.; Kurilshikov, A.; Bonder, M.J.; Valles-Colomer, M.; Vandeputte, D.; et al. Population-level analysis of gut microbiome variation. Science 2016, 352, 560-564. [CrossRef] [PubMed]

23. Peterfreund, G.L.; Vandivier, L.E.; Sinha, R.; Marozsan, A.J.; Olson, W.C.; Zhu, J.; Bushman, F.D. Succession in the Gut Microbiome following Antibiotic and Antibody Therapies for Clostridium difficile. PLoS ONE 2012, 7, e46966. [CrossRef] [PubMed]

24. Imhann, F.; Bonder, M.J.; Vila, A.V.; Fu, J.; Mujagic, Z.; Vork, L.; Tigchelaar, E.F.; Jankipersadsing, S.A.; Cenit, M.C.; Harmsen, H.J.M.; et al. Proton pump inhibitors affect the gut microbiome. Gut 2015, 65, 740-748. [CrossRef]

25. Forslund, K.; Hildebrand, F.; Nielsen, T.G.; Falony, G.; Le Chatelier, E.; Sunagawa, S.; Prifti, E.; Vieira-Silva, S.; Gudmundsdottir, V.; Pedersen, H.K.; et al. Disentangling type 2 diabetes and metformin treatment signatures in the human gut microbiota. Nature 2015, 528, 262-266. [CrossRef]

26. Tremaroli, V.; Karlsson, F.H.; Werling, M.; Ståhlman, M.; Kovatcheva-Datchary, P.; Olbers, T.; Fändriks, L.; Le Roux, C.W.; Nielsen, J.; Bäckhed, F. Roux-en-Y Gastric Bypass and Vertical Banded Gastroplasty Induce Long-Term Changes on the Human Gut Microbiome Contributing to Fat Mass Regulation. Cell Metab. 2015, 22, 228-238. [CrossRef]

27. Gentile, C.L.; Weir, T.L. The gut microbiota at the intersection of diet and human health. Science 2018, 362, 776-780. [CrossRef]

28. Noble, D.; Mathur, R.; Dent, T.; Meads, C.; Greenhalgh, T. Risk models and scores for type 2 diabetes: Systematic review. BMJ 2011, 343, d7163. [CrossRef]

29. Roglic, G. WHO Global report on diabetes: A summary. Int. J. Noncommun. Dis. 2016, 1, 3. [CrossRef]

30. Balakumar, P.; Maung, K.; Jagadeesh, G. Prevalence and prevention of cardiovascular disease and diabetes mellitus. Pharmacol. Res. 2016, 113, 600-609. [CrossRef]

31. Stanislawski, M.A.; Dabelea, D.; Lange, L.A.; Wagner, B.D.; Lozupone, C. Gut microbiota phenotypes of obesity. NPJ Biofilms Microbiomes 2019, 5, 1-9. [CrossRef] [PubMed]

32. Einarson, T.R.; Acs, A.; Ludwig, C.; Panton, U.H. Prevalence of cardiovascular disease in type 2 diabetes: A systematic literature review of scientific evidence from across the world in 2007-2017. Cardiovasc. Diabetol. 2018, 17, 83. [CrossRef] [PubMed]

33. Schmieder, R.E.; Jumar, A.; Fronk, E.M.; Alexandre, A.F.; Bramlage, P. Quality of life and emotional impact of a fixed-dose combination of antihypertensive drugs in patients with uncontrolled hypertension. J. Clin. Hypertens. 2017, 19, 126-134. [CrossRef] [PubMed]

34. Do, A.N.L.; Dagogo-Jack, S. Comorbidities of Diabetes and Hypertension: Mechanisms and Approach to Target Organ Protection. J. Clin. Hypertens. 2011, 13, 244-251.

35. Sugerman, H.J.; Wolfe, L.G.; Sica, D.A.; Clore, J.N. Diabetes and Hypertension in Severe Obesity and Effects of Gastric Bypass-Induced Weight Loss. Ann. Surg. 2003, 237, 751-758. [CrossRef] 
36. Pevsner-Fischer, M.; Blacher, E.; Tatirovsky, E.; Ben-Dov, I.Z.; Elinav, E. The gut microbiome and hypertension. Curr. Opin. Nephrol. Hypertens. 2017, 26, 1-8. [CrossRef]

37. Pasolli, E.; Truong, D.T.; Malik, F.; Waldron, L.; Segata, N. Machine Learning Meta-analysis of Large Metagenomic Datasets: Tools and Biological Insights. PLoS Comput. Boil. 2016, 12, e1004977. [CrossRef]

38. Inoue, R.; Ohue-Kitano, R.; Tsukahara, T.; Tanaka, M.; Masuda, S.; Inoue, T.; Yamakage, H.; Kusakabe, T.; Hasegawa, K.; Shimatsu, A.; et al. Prediction of functional profiles of gut microbiota from 16S rRNA metagenomic data provides a more robust evaluation of gut dysbiosis occurring in Japanese type 2 diabetic patients. J. Clin. Biochem. Nutr. 2017, 61, 217-221. [CrossRef]

39. Zhong, H.; Ren, H.; Lu, Y.; Fang, C.; Hou, G.; Yang, Z.; Chen, B.; Yang, F.; Zhao, Y.; Shi, Z.; et al. Distinct gut metagenomics and metaproteomics signatures in prediabetics and treatment-naïve type 2 diabetics. EBioMedicine 2019, 47, 373-383. [CrossRef]

40. Talley, N.J.; Spiller, R. Irritable bowel syndrome: A little understood organic bowel disease? Lancet 2002, 360, 555-564. [CrossRef]

41. Vila, A.V.; Imhann, F.; Collij, V.; Jankipersadsing, S.A.; Gurry, T.; Mujagic, Z.; Kurilshikov, A.; Bonder, M.J.; Jiang, X.; Tigchelaar, E.F.; et al. Gut microbiota composition and functional changes in inflammatory bowel disease and irritable bowel syndrome. Sci. Transl. Med. 2018, 10, eaap8914. [CrossRef] [PubMed]

42. Jones, C.M.A.; Connors, J.; Dunn, K.A.; Bielawski, J.P.; Comeau, A.M.; Langille, M.G.I.; Van Limbergen, J. Bacterial Taxa and Functions Are Predictive of Sustained Remission Following Exclusive Enteral Nutrition in Pediatric Crohn's Disease. Inflamm. Bowel Dis. 2020, 26, 1026-1037. [CrossRef]

43. Duranti, S.; Gaiani, F.; Mancabelli, L.; Milani, C.; Grandi, A.; Bolchi, A.; Santoni, A.; Lugli, G.A.; Ferrario, C.; Mangifesta, M.; et al. Elucidating the gut microbiome of ulcerative colitis: Bifidobacteria as novel microbial biomarkers. FEMS Microbiol. Ecol. 2016, 92, fiw191. [CrossRef]

44. Knoll, R.L.; Forslund, K.; Kultima, J.R.; Meyer, C.U.; Kullmer, U.; Sunagawa, S.; Bork, P.; Gehring, S. Gut microbiota differs between children with Inflammatory Bowel Disease and healthy siblings in taxonomic and functional composition: A metagenomic analysis. Am. J. Physiol. Liver Physiol. 2017, 312, G327-G339. [CrossRef] [PubMed]

45. Glass, L.M.; Hunt, C.M.; Fuchs, M.; Su, G.L. Comorbidities and Nonalcoholic Fatty Liver Disease: The Chicken, the Egg, or Both? Fed. Pract. 2019, 36, 64.

46. Wang, B.; Jiang, X.; Cao, M.; Ge, J.; Bao, Q.; Tang, L.; Chen, Y.; Li, L. Altered Fecal Microbiota Correlates with Liver Biochemistry in Nonobese Patients with Non-alcoholic Fatty Liver Disease. Sci. Rep. 2016, 6, 32002. [CrossRef] [PubMed]

47. Dong, T.S.; Katzka, W.; Lagishetty, V.; Luu, K.; Hauer, M.; Pisegna, J.; Jacobs, J.P. A Microbial Signature Identifies Advanced Fibrosis in Patients with Chronic Liver Disease Mainly Due to NAFLD. Sci. Rep. 2020, 10,1-10. [CrossRef]

48. Chen, Y.; Ji, F.; Guo, J.; Shi, D.; Fang, D.; Li, L. Dysbiosis of small intestinal microbiota in liver cirrhosis and its association with etiology. Sci. Rep. 2016, 6, 34055. [CrossRef]

49. Ashrafian, H.; Harling, L.; Darzi, A.; Athanasiou, T. Neurodegenerative disease and obesity: What is the role of weight loss and bariatric interventions? Metab. Brain Dis. 2013, 28, 341-353. [CrossRef]

50. Nussbaum, R.L.; Ellis, C.E. Alzheimer's disease and Parkinson's disease. N. Engl. J. Med. 2003, 348, 1356-1364. [CrossRef]

51. Hill-Burns, E.M.; Debelius, J.W.; Morton, J.T.; Wissemann, W.T.; Lewis, M.R.; Wallen, Z.D.; Peddada, S.D.; Factor, S.A.; Molho, E.; Zabetian, C.P.; et al. Parkinson's disease and Parkinson's disease medications have distinct signatures of the gut microbiome. Mov. Disord. 2017, 32, 739-749. [CrossRef] [PubMed]

52. Petrov, V.A.; Saltykova, I.V.; Zhukova, I.A.; Alifirova, V.M.; Zhukova, N.G.; Dorofeeva, Y.B.; Tyakht, A.V.; Kovarsky, B.A.; Alekseev, D.G.; Kostryukova, E.S.; et al. Analysis of Gut Microbiota in Patients with Parkinson's Disease. Bull. Exp. Boil. Med. 2017, 162, 734-737. [CrossRef] [PubMed]

53. Vogt, N.M.; Kerby, R.L.; Dill-McFarland, K.A.; Harding, S.J.; Merluzzi, A.P.; Johnson, S.C.; Carlsson, C.M.; Asthana, S.; Zetterberg, H.; Blennow, K.; et al. Gut microbiome alterations in Alzheimer's disease. Sci. Rep. 2017, 7, 13537. [CrossRef] [PubMed]

54. Haran, J.P.; Bhattarai, S.K.; Foley, S.E.; Dutta, P.; Ward, D.V.; Bucci, V.; McCormick, B.A.; Gilbert, J.; Faith, J. Alzheimer's Disease Microbiome Is Associated with Dysregulation of the Anti-Inflammatory P-Glycoprotein Pathway. MBio 2019, 10, e00632-19. [CrossRef] [PubMed] 
55. Geirnaert, A.; Calatayud, M.; Grootaert, C.; Laukens, D.; Devriese, S.; Smagghe, G.; De Vos, M.; Boon, N.; Van De Wiele, T. Butyrate-producing bacteria supplemented in vitro to Crohn's disease patient microbiota increased butyrate production and enhanced intestinal epithelial barrier integrity. Sci. Rep. 2017, 7, 11450. [CrossRef]

56. Wu, G.D.; Chen, J.; Hoffmann, C.; Bittinger, K.; Chen, Y.-Y.; Keilbaugh, S.A.; Bewtra, M.; Knights, D.; Walters, W.A.; Knight, R.; et al. Linking Long-Term Dietary Patterns with Gut Microbial Enterotypes. Science 2011, 334, 105-108. [CrossRef]

57. Scher, J.U.; Nayak, R.R.; Ubeda, C.; Turnbaugh, P.J.; Abramson, S.B. Pharmacomicrobiomics in inflammatory arthritis: Gut microbiome as modulator of therapeutic response. Nat. Rev. Rheumatol. 2020, 16, 282-292. [CrossRef]

58. Javdan, B.; Lopez, J.G.; Chankhamjon, P.; Lee, Y.-C.J.; Hull, R.; Wu, Q.; Wang, X.; Chatterjee, S.; Donia, M.S. Personalized Mapping of Drug Metabolism by the Human Gut Microbiome. Cell 2020, 181, 1661-1679. [CrossRef]

59. Dimidi, E.; Cox, S.R.; Rossi, M.; Whelan, K. Fermented Foods: Definitions and Characteristics, Impact on the Gut Microbiota and Effects on Gastrointestinal Health and Disease. Nutrients 2019, 11, 1806. [CrossRef]

60. Li, L.; Abou-Samra, E.; Ning, Z.; Zhang, X.; Mayne, J.; Wang, J.; Cheng, K.; Walker, K.; Stintzi, A.; Figeys, D. An in vitro model maintaining taxon-specific functional activities of the gut microbiome. Nat. Commun. 2019, 10, 1-11. [CrossRef]

61. Schellenberg, E.S.; Dryden, D.M.; VanderMeer, B.; Ha, C.; Korownyk, C. Lifestyle Interventions for Patients With and at Risk for Type 2 Diabetes. Ann. Intern. Med. 2013, 159, 543-551. [CrossRef] [PubMed]

62. Cotillard, A.; Kennedy, S.; Kong, L.C.; Prifti, E.; Pons, N.; Le Chatelier, E.; Almeida, M.; Quinquis, B.; Levenez, F.; Galleron, N.; et al. Dietary intervention impact on gut microbial gene richness. Nature 2013, 500, 585-588. [CrossRef] [PubMed]

63. Rodriguez-Castaño, G.P.; Caro-Quintero, A.; Reyes, A.; Lizcano, F. Advances in Gut Microbiome Research, Opening New Strategies to Cope with a Western Lifestyle. Front. Genet. 2017, 7, 224. [CrossRef] [PubMed]

64. Louis, S.; Tappu, R.M.; Damms-Machado, A.; Huson, D.H.; Bischoff, S.C. Characterization of the gut microbial community of obese patients following a weight-loss intervention using whole metagenome shotgun sequencing. PLOS ONE 2016, 11, e0149564. [CrossRef]

65. Shoelson, S.E.; Lee, J.; Goldfine, A.B. Inflammation and insulin resistance. J. Clin. Investig. 2006, 116, 1793-1801. [CrossRef]

66. Liu, Z.; Liu, H.-Y.; Zhou, H.; Zhan, Q.; Lai, W.; Zeng, Q.; Ren, H.; Xu, D. Moderate-Intensity Exercise Affects Gut Microbiome Composition and Influences Cardiac Function in Myocardial Infarction Mice. Front. Microbiol. 2017, 8, 1687. [CrossRef]

67. Klepser, T.B.; Kelly, M.W. Metformin hydrochloride: An antihyperglycemic agent. Am. J. Heal. Pharm. 1997, 54, 893-903. [CrossRef]

68. Madiraju, A.K.; Erion, D.M.; Rahimi, Y.; Zhang, X.-M.; Braddock, D.T.; Albright, R.A.; Prigaro, B.J.; Wood, J.L.; Bhanot, S.; Macdonald, M.J.; et al. Metformin suppresses gluconeogenesis by inhibiting mitochondrial glycerophosphate dehydrogenase. Nature 2014, 510, 542-546. [CrossRef]

69. Musi, N.; Hirshman, M.F.; Nygren, J.; Svanfeldt, M.; Bavenholm, P.; Rooyackers, O.; Zhou, G.; Williamson, J.M.; Ljunqvist, O.; Efendic, S.; et al. Metformin increases AMP-activated protein kinase activity in skeletal muscle of subjects with type 2 diabetes. Diabetes 2002, 51, 2074-2081. [CrossRef]

70. Bryrup, T.; Thomsen, C.W.; Kern, T.; Allin, K.H.; Brandslund, I.; Jørgensen, N.R.; Vestergaard, H.; Hansen, T.; Hansen, T.H.; Pedersen, O.; et al. Metformin-induced changes of the gut microbiota in healthy young men: Results of a non-blinded, one-armed intervention study. Diabetologia 2019, 62, 1024-1035. [CrossRef]

71. Ejtahed, H.-S.; Tito, R.Y.; Siadat, S.-D.; Hasani-Ranjbar, S.; Hoseini-Tavassol, Z.; Rymenans, L.; Verbeke, K.; Soroush, A.R.; Raes, J.; Larijani, B. Metformin induces weight loss associated with gut microbiota alteration in non-diabetic obese women: A randomized double-blind clinical trial. Eur. J. Endocrinol. 2019, 180, 165-176. [CrossRef] [PubMed]

72. Wu, H.; Esteve, E.; Tremaroli, V.; Khan, M.T.; Caesar, R.; Mannerås-Holm, L.; Ståhlman, M.; Olsson, L.M.; Serino, M.; Planas-Fèlix, M.; et al. Metformin alters the gut microbiome of individuals with treatment-naive type 2 diabetes, contributing to the therapeutic effects of the drug. Nat. Med. 2017, 23, 850. [CrossRef] [PubMed] 
73. Insull, W., Jr. The Pathology of Atherosclerosis: Plaque Development and Plaque Responses to Medical Treatment. Am. J. Med. 2009, 122, S3-S14. [CrossRef] [PubMed]

74. Maron, D.J.; Fazio, S.; Linton, M.F. Current perspectives on statins. Circulation 2000, 101, 207-213. [CrossRef]

75. Young, S.G.; Fong, L.G. Lowering Plasma Cholesterol by Raising LDL Receptors-Revisited. N. Engl. J. Med. 2012, 366, 1154. [CrossRef]

76. Lee, S.E.; Han, K.; Kang, Y.M.; Kim, S.-O.; Cho, Y.K.; Ko, K.S.; Park, J.-Y.; Lee, K.-U.; Koh, E.H.; on Behalf of the Taskforce Team of Diabetes Fact Sheet of the Korean Diabetes Association. Trends in the prevalence of metabolic syndrome and its components in South Korea: Findings from the Korean National Health Insurance Service Database (2009-2013). PLOS ONE 2018, 13, e0194490. [CrossRef]

77. Vieira-Silva, S.; Falony, G.; Belda, E.; Nielsen, T.G.; Aron-Wisnewsky, J.; Chakaroun, R.; Forslund, S.K.; Assmann, K.; Valles-Colomer, M.; Nguyen, T.T.D.; et al. Statin therapy is associated with lower prevalence of gut microbiota dysbiosis. Nature 2020, 581, 310-315. [CrossRef]

78. Vila, A.V.; Collij, V.; Sanna, S.; Sinha, T.; Imhann, F.; Bourgonje, A.R.; Mujagic, Z.; Jonkers, D.M.A.E.; Masclee, A.A.M.; Fu, J.; et al. Impact of commonly used drugs on the composition and metabolic function of the gut microbiota. Nat. Commun. 2020, 11, 1-11.

79. Liu, J.; LaHousse, L.; Nivard, M.G.; Bot, M.; Chen, L.; Van Klinken, J.B.; Thesing, C.S.; Beekman, M.; Akker, E.B.V.D.; Slieker, R.C.; et al. Integration of epidemiologic, pharmacologic, genetic and gut microbiome data in a drug-metabolite atlas. Nat. Med. 2020, 26, 110-117. [CrossRef]

80. Clooney, A.G.; Bernstein, C.N.; Leslie, W.D.; Vagianos, K.; Sargent, M.; Laserna-Mendieta, E.J.; Claesson, M.J.; Targownik, L.E. A comparison of the gut microbiome between long-term users and non-users of proton pump inhibitors. Aliment. Pharmacol. Ther. 2016, 43, 974-984. [CrossRef]

81. Aron-Wisnewsky, J.; Prifti, E.; Belda, E.; Ichou, F.; Kayser, B.D.; Dao, M.C.; Verger, E.; Hedjazi, L.; Bouillot, J.-L.; Chevallier, J.-M.; et al. Major microbiota dysbiosis in severe obesity: Fate after bariatric surgery. Gut 2018, 68, 70-82. [CrossRef] [PubMed]

82. Graessler, J.; Qin, Y.; Zhong, H.; Zhang, J.; Licinio, J.; Wong, M.L.; Xu, A.; Chavakis, T.; Bornstein, A.B.; Ehrhart-Bornstein, M.; et al. Metagenomic sequencing of the human gut microbiome before and after bariatric surgery in obese patients with type 2 diabetes: Correlation with inflammatory and metabolic parameters. Pharm. J. 2013, 13, 514-522. [CrossRef] [PubMed]

83. Pallejà, A.; Kashani, A.; Allin, K.H.; Nielsen, T.G.; Zhang, C.; Li, Y.; Brach, T.; Liang, S.; Feng, Q.; Jørgensen, N.B.; et al. Roux-en-Y gastric bypass surgery of morbidly obese patients induces swift and persistent changes of the individual gut microbiota. Genome Med. 2016, 8, 67. [CrossRef]

84. Lee, C.J.; Florea, L.; Sears, C.L.; Maruthur, N.; Potter, J.J.; Schweitzer, M.; Magnuson, T.; Clark, J.M. Changes in Gut Microbiome after Bariatric Surgery Versus Medical Weight Loss in a Pilot Randomized Trial. Obes. Surg. 2019, 29, 3239-3245. [CrossRef] [PubMed]

85. Murphy, R.; Tsai, P.; Jüllig, M.; Liu, A.; Krebs, J.D.; Booth, M. Differential Changes in Gut Microbiota after Gastric Bypass and Sleeve Gastrectomy Bariatric Surgery Vary According to Diabetes Remission. Obes. Surg. 2016, 27, 917-925. [CrossRef]

86. Ülker, I.; Yildiran, H. The effects of bariatric surgery on gut microbiota in patients with obesity: A review of the literature. Biosci. Microbiota Food Health 2018, 38, 3-9. [CrossRef]

87. Al Assal, K.; Prifti, E.; Belda, E.; Sala, P.C.; Clemént, K.; Dao, M.-C.; Doré, J.; Levenez, F.; Taddei, C.R.; Fonseca, D.C.; et al. Gut Microbiota Profile of Obese Diabetic Women Submitted to Roux-en-Y Gastric Bypass and Its Association with Food Intake and Postoperative Diabetes Remission. Nutrients 2020, 12, 278. [CrossRef]

88. Soletsky, B.; Feig, D.I. Uric Acid Reduction Rectifies Prehypertension in Obese Adolescents. Hypertension 2012, 60, 1148-1156. [CrossRef]

89. Karlsson, F.H.; Fåk, F.; Nookaew, I.; Tremaroli, V.; Fagerberg, B.; Petranovic, D.; Bäckhed, F.; Nielsen, J. Symptomatic atherosclerosis is associated with an altered gut metagenome. Nat. Commun. 2012, 3, 1245. [CrossRef]

90. Kampoli, A.-M.; Tousoulis, D.; Antoniades, C.; Siasos, G.; Stefanadis, C. Biomarkers of premature atherosclerosis. Trends Mol. Med. 2009, 15, 323-332. [CrossRef]

91. Bhole, V.; Choi, J.W.J.; Kim, S.W.; De Vera, M.; Choi, H. Serum Uric Acid Levels and the Risk of Type 2 Diabetes: A Prospective Study. Am. J. Med. 2010, 123, 957-961. [CrossRef] [PubMed] 
92. Chakraborty, A.; Chowdhury, S.; Bhattacharyya, M. Effect of metformin on oxidative stress, nitrosative stress and inflammatory biomarkers in type 2 diabetes patients. Diabetes Res. Clin. Pract. 2011, 93, 56-62. [CrossRef] [PubMed]

93. Fernández-Bergés, D.; Consuegra-Sanchez, L.; Penafiel, J.; De León, A.C.; Vila, J.; Félix-Redondo, F.J.; Segura-Fragoso, A.; Lapetra, J.; Guembe, M.J.; Vega, T.; et al. Metabolic and Inflammatory Profiles of Biomarkers in Obesity, Metabolic Syndrome, and Diabetes in a Mediterranean Population. DARIOS Inflammatory Study. Revista Española Cardiología (Engl. Ed.) 2014, 67, 624-631. [CrossRef]

94. Pouliot, M.-C.; Després, J.-P.; Nadeau, A.; Moorjani, S.; Prud'Homme, D.; Lupien, P.J.; Tremblay, A.; Bouchard, C. Visceral Obesity in Men: Associations with Glucose Tolerance, Plasma Insulin, and Lipoprotein Levels. Diabetes 1992, 41, 826-834. [CrossRef] [PubMed]

95. Jennis, M.; Cavanaugh, C.R.; Leo, G.C.; Mabus, J.R.; Lenhard, J.; Hornby, P.J. Microbiota-derived tryptophan indoles increase after gastric bypass surgery and reduce intestinal permeability in vitro and in vivo. Neurogastroenterol. Motil. 2017, 30, e13178. [CrossRef] [PubMed]

96. Cason, C.A.; Dolan, K.T.; Sharma, G.; Tao, M.; Kulkarni, R.; Helenowski, I.B.; Doane, B.M.; Avram, M.J.; McDermott, M.M.; Chang, E.B.; et al. Plasma microbiome-modulated indole- and phenyl-derived metabolites associate with advanced atherosclerosis and postoperative outcomes. J. Vasc. Surg. 2017, 68, 1552-1562. [CrossRef] [PubMed]

97. Monteleone, I.; Rizzo, A.; Sarra, M.; Sica, G.; Sileri, P.; Biancone, L.; Macdonald, T.T.; Pallone, F.; Monteleone, G. Aryl Hydrocarbon Receptor-Induced Signals Up-regulate IL-22 Production and Inhibit Inflammation in the Gastrointestinal Tract. Gastroenterology 2011, 141, 237-248. [CrossRef]

98. Kadow, S.; Jux, B.; Zahner, S.P.; Wingerath, B.; Chmill, S.; Clausen, B.E.; Hengstler, J.G.; Esser, C. Aryl Hydrocarbon Receptor Is Critical for Homeostasis of Invariant $\gamma \delta$ T Cells in the Murine Epidermis. J. Immunol. 2011, 187, 3104-3110. [CrossRef]

99. Shah, S.H.; Bain, J.; Muehlbauer, M.J.; Stevens, R.D.; Crosslin, D.R.; Haynes, C.; Dungan, J.; Newby, L.K.; Hauser, E.R.; Ginsburg, G.S.; et al. Association of a Peripheral Blood Metabolic Profile with Coronary Artery Disease and Risk of Subsequent Cardiovascular Events. Circ. Cardiovasc. Genet. 2010, 3, 207-214. [CrossRef]

100. Okekunle, A.P.; Li, Y.; Liu, L.; Du, S.; Wu, X.; Chen, Y.; Li, Y.; Qi, J.; Sun, C.-H.; Feng, R. Abnormal circulating amino acid profiles in multiple metabolic disorders. Diabetes Res. Clin. Pract. 2017, 132, 45-58. [CrossRef]

101. Mangge, H.; Zelzer, S.; Prueller, F.; Schnedl, W.J.; Weghuber, D.; Enko, D.; Bergsten, P.; Haybaeck, J.; Meinitzer, A. Branched-chain amino acids are associated with cardiometabolic risk profiles found already in lean, overweight and obese young. J. Nutr. Biochem. 2016, 32, 123-127. [CrossRef] [PubMed]

102. Lee, J.; Jung, S.; Kim, N.; Shin, M.-J.; Ryu, D.H.; Hwang, G.-S. Myocardial metabolic alterations in mice with diet-induced atherosclerosis: Linking sulfur amino acid and lipid metabolism. Sci. Rep. 2017, 7, 13597. [CrossRef] [PubMed]

103. Zhao, L.; Zhang, F.; Ding, X.; Wu, G.; Lam, Y.Y.; Wang, X.; Fu, H.; Xue, X.; Lu, C.; Ma, J.; et al. Gut bacteria selectively promoted by dietary fibers alleviate type 2 diabetes. Science 2018, 359, 1151-1156. [CrossRef] [PubMed]

104. Kim, K.-N.; Yao, Y.; Ju, S.-Y. Short Chain Fatty Acids and Fecal Microbiota Abundance in Humans with Obesity: A Systematic Review and Meta-Analysis. Nutrients 2019, 11, 2512. [CrossRef]

105. Lefebvre, P.; Cariou, B.; Lien, F.; Kuipers, F.; Staels, B. Role of Bile Acids and Bile Acid Receptors in Metabolic Regulation. Physiol. Rev. 2009, 89, 147-191. [CrossRef]

106. Miettinen, T.A.; Gylling, H. Cholesterol absorption efficiency and sterol metabolism in obesity. Atherosclerosis 2000, 153, 241-248. [CrossRef]

107. Charach, G.; Rabinovich, A.; Argov, O.; Weintraub, M.; Rabinovich, P. The Role of Bile Acid Excretion in Atherosclerotic Coronary Artery Disease. Int. J. Vasc. Med. 2012, 2012, 949672. [CrossRef]

108. Hofmann, A.F. Bile Acids: The Good, the Bad, and the Ugly. Physiology 1999, 14, 24-29. [CrossRef]

109. Gregorio, F.; Ambrosi, F.; Filipponi, P.; Manfrini, S.; Testa, I. Is metformin safe enough for ageing type 2 diabetic patients? Diabetes Metab. 1996, 22, 43-50.

110. Pihlajamäki, J.; Grönlund, S.; Simonen, M.; Käkelä, P.; Moilanen, L.; Pääkkönen, M.; Pirinen, E.; Kolehmainen, M.; Kärjä, V.; Kainulainen, S.; et al. Cholesterol absorption decreases after Roux-en-Y gastric bypass but not after gastric banding. Metabolism 2010, 59, 866-872. [CrossRef] 
111. Furet, J.-P.; Kong, L.-C.; Tap, J.; Poitou, C.; Basdevant, A.; Bouillot, J.-L.; Mariat, D.; Corthier, G.; Doré, J.; Henegar, C.; et al. Differential Adaptation of Human Gut Microbiota to Bariatric Surgery-Induced Weight Loss: Links with Metabolic and Low-Grade Inflammation Markers. Diabetes 2010, 59, 3049-3057. [CrossRef] [PubMed]

112. Oberbach, A.; Neuhaus, J.; Inge, T.; Kirsch, K.; Schlichting, N.; Blüher, S.; Kullnick, Y.; Kugler, J.; Baumann, S.; Till, H. Bariatric surgery in severely obese adolescents improves major comorbidities including hyperuricemia. Metabolism 2014, 63, 242-249. [CrossRef] [PubMed]

113. Alfaras, I.; Mitchell, S.J.; Mora, H.; Lugo, D.R.; Warren, A.; Navas-Enamorado, I.; Hoffmann, V.; Hine, C.; Mitchell, J.R.; Le Couteur, D.G.; et al. Health benefits of late-onset metformin treatment every other week in mice. NPJ Aging Mech. Dis. 2017, 3, 16. [CrossRef]

114. Simonen, M.; Dali-Youcef, N.; Kaminska, D.; Venesmaa, S.; Kakela, P.; Pääkkönen, M.; Hallikainen, M.; Kolehmainen, M.; Uusitupa, M.; Moilanen, L.; et al. Conjugated bile acids associate with altered rates of glucose and lipid oxidation after Roux-en-Y gastric bypass. Obes. Surg. 2012, 22, 1473-1480. [CrossRef] [PubMed]

115. McCreight, L.J.; Bailey, C.J.; Pearson, E.R. Metformin and the gastrointestinal tract. Diabetologia 2016, 59, 426-435. [CrossRef]

116. Wijayatunga, N.N.; Sams, V.G.; Dawson, J.A.; Mancini, M.L.; Mancini, G.J.; Moustaid-Moussa, N. Roux-en-Y gastric bypass surgery alters serum metabolites and fatty acids in patients with morbid obesity. Diabetes Metab. Res. Rev. 2018, 34, e3045. [CrossRef] [PubMed]

117. Preiss, D.; Rankin, N.; Welsh, P.; Holman, R.R.; Kangas, A.J.; Soininen, P.; Würtz, P.; Ala-Korpela, M.; Sattar, N. Effect of metformin therapy on circulating amino acids in a randomized trial: The CAMERA study. Diabet. Med. 2016, 33, 1569-1574. [CrossRef]

118. Martinez, K.B.; Mackert, J.D.; McIntosh, M.K. Polyphenols and intestinal health. In Nutrition and Functional Foods for Healthy Aging; Elsevier: Amsterdam, The Netherlands, 2017; pp. 191-210.

119. Subramanian, I.; Verma, S.; Kumar, S.; Jere, A.; Anamika, K. Multi-omics Data Integration, Interpretation, and Its Application. Bioinform. Boil. Insights 2020, 14, 1177932219899051. [CrossRef]

120. Karlsson, F.H.; Nookaew, I.; Petranovic, D.; Nielsen, J. Prospects for systems biology and modeling of the gut microbiome. Trends Biotechnol. 2011, 29, 251-258. [CrossRef]

121. Mardinoglu, A.; Borén, J.; Smith, U.; Uhlén, M.; Nielsen, J. Systems biology in hepatology: Approaches and applications. Nat. Rev. Gastroenterol. Hepatol. 2018, 15, 365-377. [CrossRef]

122. Green, S.; Şerban, M.; Scholl, R.; Jones, N.; Brigandt, I.; Bechtel, W. Network analyses in systems biology: New strategies for dealing with biological complexity. Synthese 2017, 195, 1751-1777. [CrossRef]

123. Hill, C.B.; Czauderna, T.; Klapperstück, M.; Roessner, U.; Schreiber, F. Metabolomics, Standards, and Metabolic Modeling for Synthetic Biology in Plants. Front. Bioeng. Biotechnol. 2015, 3, 167. [CrossRef] [PubMed]

124. O’Brien, E.J.; Monk, J.; Palsson, B.O. Using Genome-scale Models to Predict Biological Capabilities. Cell 2015, 161, 971-987. [CrossRef] [PubMed]

125. Väremo, L.; Nookaew, I.; Nielsen, J. Novel insights into obesity and diabetes through genome-scale metabolic modeling. Front. Physiol. 2013, 4, 92. [CrossRef] [PubMed]

126. Ghaffari, P.; Mardinoglu, A.; Asplund, A.; Shoaie, S.; Kampf, C.; Uhlen, M.; Nielsen, J. Identifying anti-growth factors for human cancer cell lines through genome-scale metabolic modeling. Sci. Rep. 2015, 5, 8183. [CrossRef]

127. Magnúsdóttir, S.; Heinken, A.; Kutt, L.; Ravcheev, D.A.; Bauer, E.; Noronha, A.; Greenhalgh, K.; Jäger, C.; Baginska, J.; Wilmes, P.; et al. Generation of genome-scale metabolic reconstructions for 773 members of the human gut microbiota. Nat. Biotechnol. 2016, 35, 81. [CrossRef]

128. Zomorrodi, A.R.; Maranas, C.D. OptCom: A Multi-Level Optimization Framework for the Metabolic Modeling and Analysis of Microbial Communities. PLoS Comput. Boil. 2012, 8, e1002363. [CrossRef]

129. Shoaie, S.; Karlsson, F.H.; Mardinoglu, A.; Nookaew, I.; Bordel, S.; Nielsen, J. Understanding the interactions between bacteria in the human gut through metabolic modeling. Sci. Rep. 2013, 3, 2532. [CrossRef]

130. Shoaie, S.; Ghaffari, P.; Kovatcheva-Datchary, P.; Mardinoglu, A.; Sen, P.; Pujos-Guillot, E.; De Wouters, T.; Juste, C.; Rizkalla, S.; Chilloux, J.; et al. Quantifying Diet-Induced Metabolic Changes of the Human Gut Microbiome. Cell Metab. 2015, 22, 320-331. [CrossRef] 
131. Brunk, E.; Sahoo, S.; Zielinski, D.C.; Altunkaya, A.; Dräger, A.; Mih, N.; Gatto, F.; Nilsson, A.; Le, H.M.; Aurich, M.K.; et al. Recon3D enables a three-dimensional view of gene variation in human metabolism. Nat. Biotechnol. 2018, 36, 272. [CrossRef]

132. Heinken, A.; Sahoo, S.; Fleming, R.M.T.; Thiele, I. Systems-level characterization of a host-microbe metabolic symbiosis in the mammalian gut. Gut Microbes 2013, 4, 28-40. [CrossRef] [PubMed]

133. Baldini, F.; Heinken, A.; Heirendt, L.; Magnusdottir, S.; Fleming, R.M.T.; Thiele, I. The Microbiome Modeling Toolbox: From microbial interactions to personalized microbial communities. Bioinformatics 2018, 35, 2332-2334. [CrossRef] [PubMed]

(C) 2020 by the authors. Licensee MDPI, Basel, Switzerland. This article is an open access article distributed under the terms and conditions of the Creative Commons Attribution (CC BY) license (http://creativecommons.org/licenses/by/4.0/). 